\section{Ross-River-Viren (RRV)}

W. Stöcker

Euroimmun Medizinische Labordiagnostika AG, Lübeck, Deutschland

\section{Englischer Begriff Ross River virus}

Beschreibung des Erregers Familie: Togaviridiae; Gattung: Alphavirus; Art: Ross-River-Virus. Plusstrang-RNAGenom, behüllt, 60-70 nm Durchmesser; enge Verwandtschaft zu Barmah-Forest-Viren.

Erkrankungen Vorkommen: Australien.

Vektoren: Stechmücken (Aedes ssp., insbesondere Aedes vigilax, Culex spp., z. B. Culex annulirostris).

Wirte: Menschen; Wallabys und die australische Rattenart Rattus colletti dienen vermutlich als Virusreservoir.

Klinik: endemische Polyarthritis; mit etwa 5000 Registrierungen pro Jahr gilt die RRV-Infektion als bedeutendste arbovirale Infektionskrankheit in Australien. Nach einer Inkubationszeit von 7-9 Tagen können Fieber, Arthralgie, häufig mit Arthritis, Myalgie, Hautausschlag und Lethargie auftreten; häufiger als bei BFV-(Barmah-Forest-Virus-)Infektionen persistieren Arthralgie und Myalgie für länger als 6 Monate.

Analytik Direktnachweis: Virusisolation oder Nachweis viraler RNA durch RT-PCR (Polymerase-Kettenreaktion).

Serologie: Nachweis spezifischer Antikörper (IgM, IgG) im Serum durch indirekte Immunfluoreszenz, Enzyme-linked Immunosorbent-Assay oder Neutralisationstest.
Probenmaterial Direktnachweis: Blut und Blutbestandteile, Gewebe. Das Material sollte bis zur Weiterverarbeitung bei +4 bis $+8{ }^{\circ} \mathrm{C}$ aufbewahrt werden.

Serologie: Serum oder Plasma für den Nachweis der Antikörper sind bei $+4{ }^{\circ} \mathrm{C}$ bis zu 2 Wochen lang beständig, bei $-20{ }^{\circ} \mathrm{C}$ über Monate und Jahre hinweg. Zur Tiefkühlkonservierung des IgM kann man den Proben $80 \%$ gepuffertes Glyzerin beifügen.

Diagnostische Wertigkeit Die Anamnese, insbesondere Informationen über längere Aufenthalte in Endemiegebieten ist wichtig. Der direkte Virusnachweis ist grundsätzlich möglich, serologische Tests zum Nachweis von Antikörpern sind jedoch vorzuziehen. $\mathrm{Zu}$ Beginn der Symptomatik sind spezifische IgM-Antikörper bei der Mehrzahl der Patienten vorhanden. Ein gegenüber der ersten Probe gemessener signifikanter Anstieg des Anti-RRV-IgG-Titers in einer zweiten Serumprobe (Abstand zwischen den Blutentnahmen ca. 2 Wochen) gilt als sicherer Beleg für die Infektion. Kreuzreaktivitäten mit Antikörpern gegen koendemische Alphaviren sind möglich.

\section{Literatur}

Dobler G, Aspöck H (2010) Durch Stechmücken übertragene Arboviren als Erreger von Infektionen des Menschen. In Aspöck H (Hrsg) Krank durch Arthroponden, Denisia 30:501-553

Jacups SP, Whelan PI, Currie BJ (2008) Ross River virus and Barmah Forest virus infections: a review of history, ecology, and predictive models, with implications for tropical northern Australia. Vector Borne Zoonotic Dis 8(2):283-297

Robert-Koch-Institut (Hrsg) (2011) Steckbriefe seltener und importierter Infektionskrankheiten. Berlin 